\title{
Renal Lesions of Subacute Infective Endocarditis
}

\author{
J. M. BOULTON-JONES, J. G. P. SISSONS, D. J. EVANS, D. K. PETERS
}

British Medical Fournal, 1974, 2, 11-14

\section{Summary}

This paper gives an account of five patients with glomerulonephritis complicating subacute infective endocarditis. In three patients with focal (segmental) glomerulonephritis granular deposits of immunoglobulin and $C 3$ and reduced serum complement suggested an immune-complex aetiology; but in two patients with a diffuse proliferative glomerulonephritis no Ig or C3 was detected in the diseased glomeruli and the pathogenetic mechanism remained undetermined. Four of the five patients developed renal failure needing dialysis.

\section{Introduction}

Infective endocarditis has long been known to cause glomerular disease though this is rarely of serious clinical significance (Baehr, 1921). Most workers have distinguished two morphological patterns of injury-a diffuse and a focal glomerulonephritis (Gutman et al., 1972; Heptinstall, 1966)-though there has been no agreement on the pathogenesis or interrelationship between them. We describe here the clinical and immunopathological findings in five patients with glomerulonephritis complicating subacute infective endocarditis. In three patients there was evidence that nephritis was due to antigen-antibody complexes but in two patients no immunoglobulin or complement could be detected in the diseased glomeruli. These patients were also unusual in that four developed severe renal failure needing dialysis.

\section{Case Reports}

Case 1.-In October 1970 a 60 -year-old man had an attack of bronchopneumonia. This responded to antibiotics but he continued to have recurrent episodes of fever each responding temporarily to short courses of ampicillin. In April 1971 mitral incompetence was diagnosed and he was treated with ampicillin and cloxacillin for six weeks though blood cultures were sterile. He improved again for a short period but symptoms recurred and in November 1971 he was admitted to Hammersmith Hospital. On examination he had signs of mitral regurgitation, lymphadenopathy, and hepatosplenomegaly. Proteinuria fluctuated between 0.9 and $7.7 \mathrm{~g} / 24$ hours and creatinine clearance was reduced to $26 \mathrm{ml} / \mathrm{min}$. Out of 15 blood cultures five grew Actinobacillus actinomycetumcomitans. Despite treatment with penicillin and gentamicin for six weeks, renal function deteriorated and he needed peritoneal dialysis for three weeks. Renal biopsy three weeks after the start of treatment showed 10 glomeruli, in two of which there were crescents. Most of the glomeruli showed extensive proliferation within the tufts but in the least-affected glomeruli damage was segmental (figs. 1 and 2). Because the renal lesion was so severe and blood cultures sterile he was given prednisolone $60 \mathrm{mg} /$ day but this had to be stopped because of gastrointestinal haemorrhage. Renal function gradually improved and on discharge the blood urea was $52 \mathrm{mg} / 100 \mathrm{ml}$ and the 24 -hour urine protein $0.5 \mathrm{~g}$.

Departments of Medicine and Pathology, Royal Postgraduate Medical School, Ducane Road, London W12 0HS

J. M. BOULTON-JONES, M.B., M.R.C.P., Senior Registrar

J. G. P. SISSONS, M.B., M.R.C.P., Registrar

D. J. EVANS, M.B., Senior Lecturer in Histopathology

D. K. PETERS, M.B., M.R.C.P., Lecturer in Medicine and Immunology

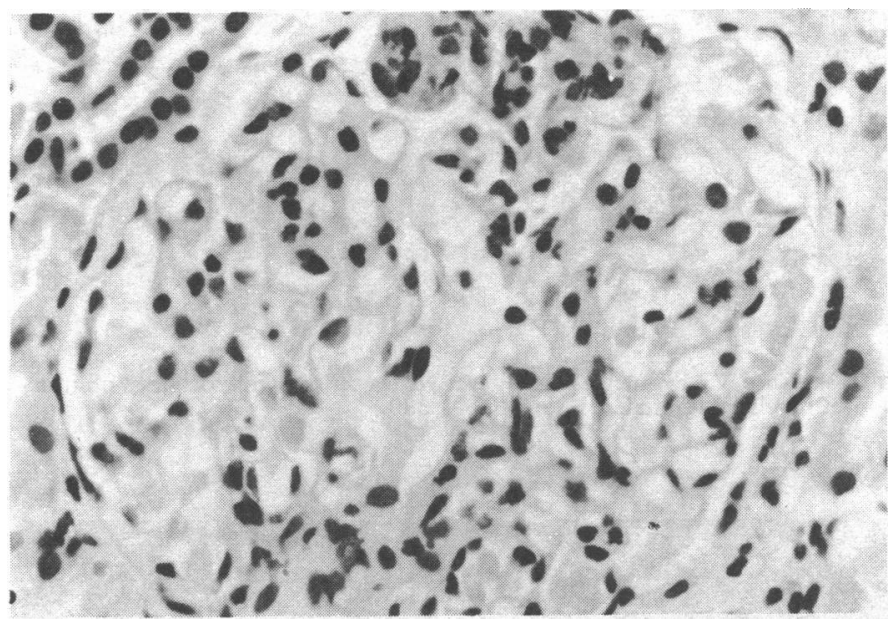

FIG. 1-Case 1. Least affected glomerulus showing segmental sclerosis. (H. and E. $\times 320$.)

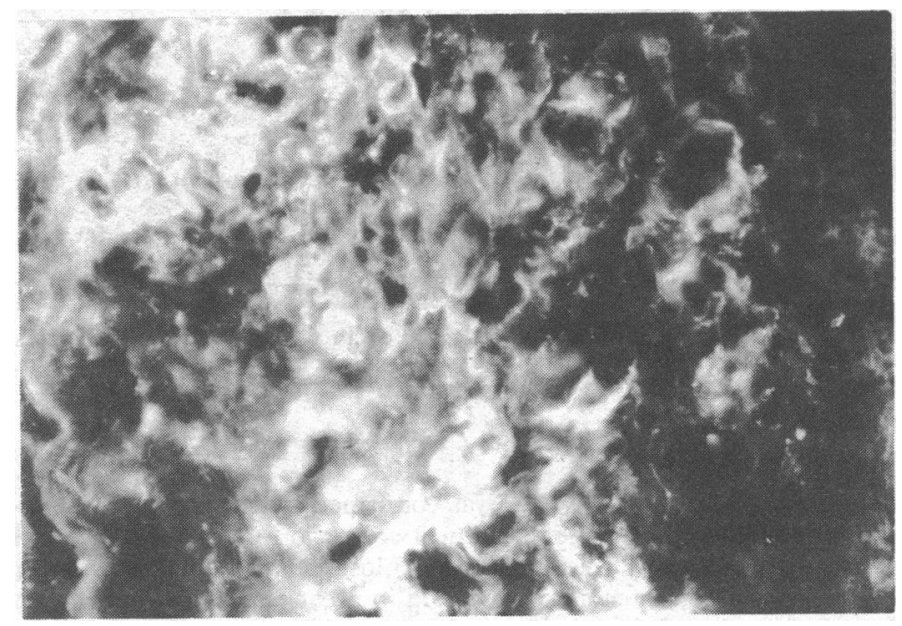

FIG. 2-Case 1. Immunofluorescent appearances of typical glomerulus showing scattered deposits of $\mathrm{C} 3$ along capillary walls. (Fluoresceinated anti-C3. $\times 340$.)

Case 2.-A 57-year-old man with rheumatic aortic valve disease presented with a 12-month history of increasing dyspnoea and malaise; six months earlier he had had a short febrile illness. On examination there were signs of aortic regurgitation, hepatosplenomegaly, finger clubbing, and persistent fever. The serum creatinine was $2.0 \mathrm{mg} / 100$ $\mathrm{ml}$ and the urine contained red cells but no protein. Repeated blood cultures were sterile but a high titre $(1: 1,024)$ of complement-fixing antibody to psittacosis/lymphogranuloma venereum (L.G.V.) antigen was detected. A diagnosis of psittacosis endocarditis was therefore made and treatment with tetracycline and rifampicin was begun. A renal biopsy five days later showed minor focal proliferative changes (figs. 3 and 4). The serum creatinine fell progressively to $1.5 \mathrm{mg} / 100$ $\mathrm{ml}$. He improved temporarily but four months later, because of a return of fever, increasing aortic regurgitation, and a fall in C3 concentration, recurrent infection was diagnosed and the aortic valve replaced. At operation a bicuspid aortic valve was found to be covered in vegetations. Postoperatively his serum creatinine was $1.4 \mathrm{mg} / 100 \mathrm{ml}$ and 6 months later the antibody titre to psittacosis/L.G.V. antigen had fallen to $1: 16$. He has continued on tetracycline and rifampicin.

Case 3.-The patient was a 25-year-old man in whom a heart murmur had been discovered at the age of 4 months and the clinical 


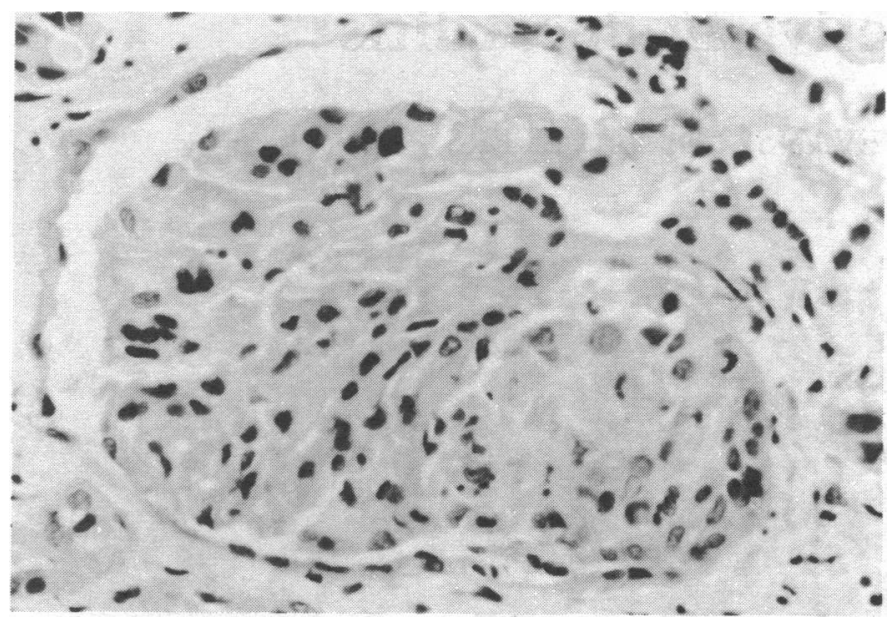

FIG. 3-Case 2. Segmental proliferative lesion showing localized obliteration of capillary lumina. (H. and E. $\times 380$.)

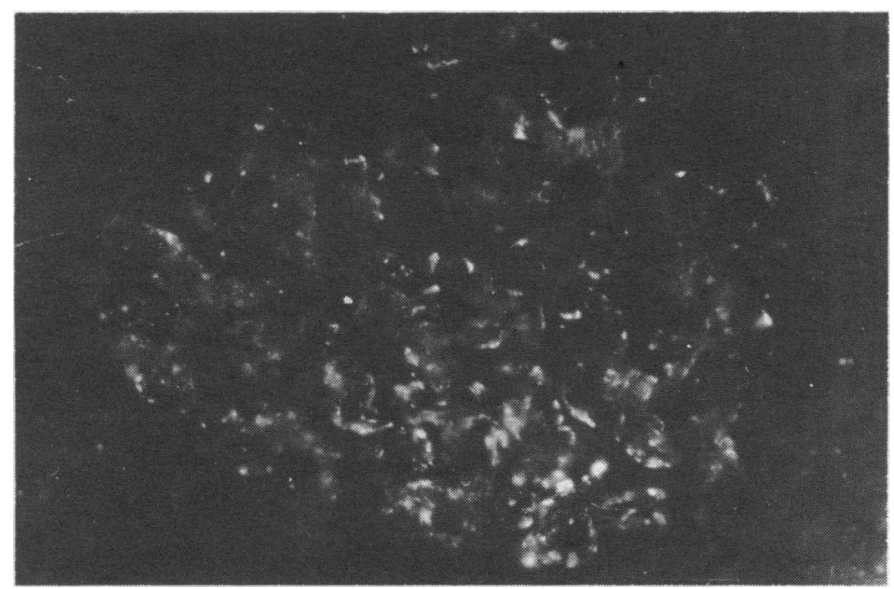

FIG. 4-Case 2. Immunofluorescent appearances of typical glomerulus showing extensive granular deposition of IgG along capillary walls and in mesangial regions. (Fluoresceinated anti-C $3 . \times 310$.)

diagnosis of tetralogy of Fallot was confirmed by cardiac catheterization at the age of 13. A total surgical correction performed the next year, leaving a small residual ventriculoseptal defect and a minor degree of pulmonary stenosis, resulted in great clinical improvement. He continued well for nine years but then became tired and unwell and was found to be anaemic (haemoglobin $9 \mathrm{~g} / 100 \mathrm{ml}$ ). One month later he had a haematemesis and was admitted to hospital, where he was found to have renal failure (blood urea $400 \mathrm{mg} / 100 \mathrm{ml}$ ). Blood cultures grew Streptococcus viridans. He was transferred to Hammersmith Hospital, where treatment with peritoneal dialysis and penicillin was started. Renal biopsy 27 days later showed seven out of eight glomeruli entirely sclerosed; the eighth showed a segmental proliferative glomerulonephritis. No improvement in renal function occurred over a period of three months and he ultimately died of staphylococcal septicaemia. At necropsy friable vegetations were present on the mitral and tricuspid valves and on the suture line of the patch in the pulmonary artery. The kidneys were of normal size. Ninety per cent. of the glomeruli were sclerosed and the remainder showed adhesions between capillary loops and Bowman's capsule.

Case 4.- This patient was a 54-year-old Persian man with rheumatic disease of the aortic and mitral valves. These had been replaced by Starr-Edwards prostheses in May 1972. The blood urea had been $28 \mathrm{mg} / 100 \mathrm{ml}$ when he was discharged from hospital on the 10th postoperative day. Two months later he had rigors and was found to have atrial fibrillation. An unsuccessful attempt at cardioversion was followed by gastrointestinal bleeding. From that time he continued to have intermittent fevers. On investigation in Teheran the blood urea was $96 \mathrm{mg} / 100 \mathrm{ml}$ and the urine contained protein ( $3 \mathrm{~g} / 24$ hours), red cells, and casts. He was readmitted to Hammersmith Hospital in November 1972 when the blood urea was $212 \mathrm{mg} / 100 \mathrm{ml}$, though it had been only $62 \mathrm{mg} / 100 \mathrm{ml} 10$ days earlier. The haemoglobin was
$4.7 \mathrm{~g} / 100 \mathrm{ml}$. Three blood cultures grew Staphylococcus albus. $\mathrm{He}$ was treated by peritoneal dialysis for 16 days and with gentamicin, rifamicin, and lincomicin for six weeks. Renal biopsy seven days after the start of treatment showed histological evidence suggesting acute tubular necrosis and diffuse mesangio-proliferative glomerulonephritis without neutrophil polymorph infiltration. When discharged from hospital the blood urea had fallen to $34 \mathrm{mg} / 100 \mathrm{ml}$ and the urine was free of protein.

Case 5.-A 62-year-old man presented with a short history of fever and proteinuria. On admission to hospital he was thought to be dehydrated but on rehydration remained oliguric and was found to be uraemic. On transfer to Hammersmith Hospital he was confused and suffering from severe congestive heart failure. Despite assisted ventilation and peritoneal dialysis he deteriorated and died the next day. At necropsy the mitral valve leaflets were found to be thickened and the chordae shortened. There were small vegetations along the line of valve closure and an ulcer $(4 \times 2 \mathrm{~mm})$ on the anterior cusp. Histological examination showed an acute inflammatory reaction with sheets of Gram-positive cocci within the valve. The kidneys were of normal size but microscopy showed a diffuse lobular proliferative glomerulonephritis (fig. 5).

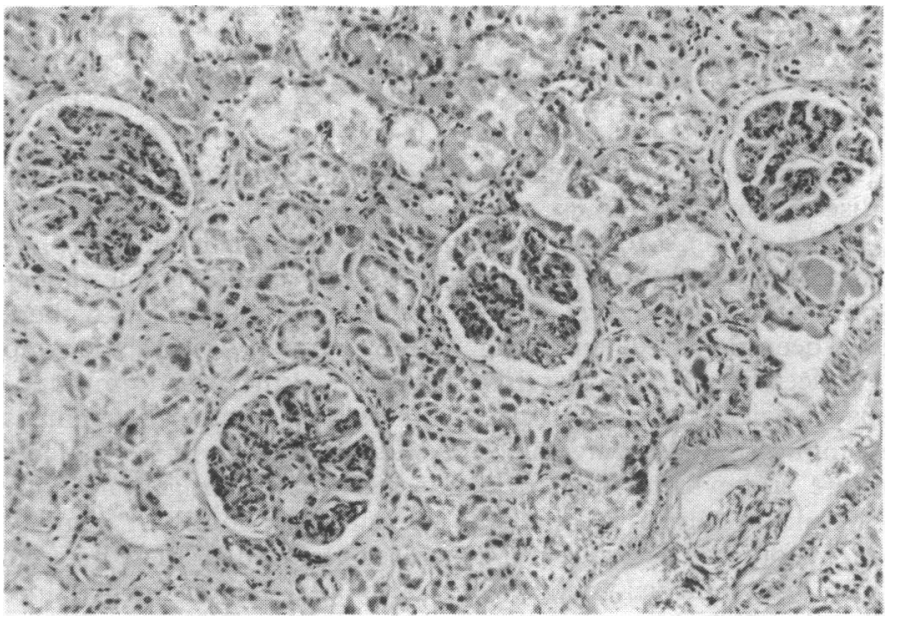

FIG. 5-Case 5. Necropsy kidney specimen showing diffuse mesangial proliferative glomerulonephritis. (H. and E. $\times 145$.)

\section{Methods}

The serum concentrations of the complement components C3, C4, CIq, glycine-rich beta glycoprotein (GBG), and properdin were measured as described previously (Williams et al., 1973). The methods and antisera used for immunofluorescence have been described previously (Evans et al., 1973) as have the methods used for light microscopy (Macanovic et al., 1972). In two patients (cases 1 and 2) whose glomeruli contained immunoglobulins there was sufficient biopsy material to attempt identification of antigen. The IgG fraction of convalescent serum from Case 1 was fluoresceinated by standard techniques (Nairn, 1969) and shown to react with the organism by direct immunofluorescence. Fluoresceinated serum was then layered on cryostat sections which were untreated and prewashed in citrate buffer ( $\mathrm{pH} 3 \cdot 2$ ) and then in phosphate-buffered saline. Biopsy material from case 2 was eluted with citrate buffer ( $\mathrm{pH} \mathrm{3 \cdot 2)}$ according to the method of Feltkamp and Boode (1970). The eluate was neutralized and tested for psittacosis antigen and antibody by a micro complement fixation test (Meyer et al., 1969) and for antibody by indirect immunofluorescence.

\section{Results}

Renal biopsy findings are summarized in table I (see also figs. 2 and 4). Attempts to find antigen or specific antibody in the glomeruli of the patients in cases 1 and 2 failed. Complement studies are summarized in table II. Low C3 concentrations were 
TABLE I-Renal Biopsy Findings in five Patients with Subacute Infective Endocarditis

\begin{tabular}{|c|c|c|c|c|c|c|}
\hline \multirow{2}{*}{$\begin{array}{l}\text { Case } \\
\text { No. }\end{array}$} & \multirow{2}{*}{ Light Microscopy } & \multicolumn{4}{|c|}{ Immunofluorescence } & \multirow{2}{*}{ Thin Section } \\
\hline & & $\mathrm{IgG}$ & $\operatorname{Ig} A$ & $\operatorname{Ig} M$ & $\mathrm{C} 3$ & \\
\hline 1 & $\begin{array}{l}\text { Extensive proliferative glomerular changes } \\
\text { with segmental distribution in least } \\
\text { affected glomeruli }\end{array}$ & $\begin{array}{l}\text { Diffuse granular } \\
\text { parietal }\end{array}$ & 0 & $\begin{array}{l}\text { Diffuse granular } \\
\text { parietal }\end{array}$ & $\begin{array}{l}\text { Diffuse granular } \\
\text { parietal }\end{array}$ & $\begin{array}{l}\text { Badly damaged glomerulus. } \\
\text { Subendothelial deposits? }\end{array}$ \\
\hline 2 & $\begin{array}{l}\text { Mild segmental and focal proliferative } \\
\text { glomerulonephritis }\end{array}$ & $\begin{array}{l}\text { Diffuse granular } \\
\text { parietal and } \\
\text { mesangial }\end{array}$ & 0 & $\begin{array}{l}\text { Diffuse granular } \\
\text { parietal and } \\
\text { mesangial }\end{array}$ & $\begin{array}{l}\text { Diffuse granular } \\
\text { parietal and } \\
\text { mesangial }\end{array}$ & $\begin{array}{l}\text { Subendothelial and mesangial } \\
\text { deposits }\end{array}$ \\
\hline 3 & $\begin{array}{l}\text { Segmental proliferation in one } \\
\text { glomerulus. Remaining } 7 \text { glomeruli }\end{array}$ & mesangial & $\begin{array}{l}\text { Diffuse granular } \\
\text { parietal and }\end{array}$ & $\begin{array}{l}\text { Diffuse granular } \\
\text { parietal and }\end{array}$ & $\begin{array}{l}\text { Diffuse granular } \\
\text { parietal and }\end{array}$ & $\begin{array}{l}\text { Subendothelial and mesangial } \\
\text { deposits }\end{array}$ \\
\hline 4 & Diffuse mesangial proliferative & 0 & 0 & 0 & 0 & No deposits seen \\
\hline 5 & $\begin{array}{l}\text { Diffuse mesangial proliferative } \\
\text { glomerulonephritis }\end{array}$ & 0 & 0 & 0 & 0 & No deposits seen \\
\hline
\end{tabular}

TABLE II-Serum Complement Levels of four Patients with Subacute Infective Endocarditis before and after Treatment. Figures are Percentages of Pooled Normal Serum

\begin{tabular}{|c|c|c|c|c|c|c|c|}
\hline & & \multicolumn{5}{|c|}{ Case No. } & \multirow{3}{*}{$\begin{array}{l}\text { Normal } \\
\text { Ranges }\end{array}$} \\
\hline & & \multirow{2}{*}{1} & \multicolumn{2}{|c|}{2} & \multirow{2}{*}{3} & \multirow{2}{*}{4} & \\
\hline & & & $a^{*}$ & $b^{*}$ & & & \\
\hline \multirow{2}{*}{ C3 } & C Before & 60 & 55 & 55 & 25 & 100 & \multirow{2}{*}{$68-116$} \\
\hline & $\left\{\begin{array}{l}\text { After } \\
\text { Before }\end{array}\right.$ & $\begin{array}{r}100 \\
72\end{array}$ & $\begin{array}{l}90 \\
35\end{array}$ & $\begin{array}{r}100 \\
40\end{array}$ & $\begin{array}{r}100 \\
52\end{array}$ & $\begin{array}{l}120 \\
100\end{array}$ & \\
\hline C4 & $\begin{array}{l}\text { After } \\
\text { Before }\end{array}$ & $\begin{array}{l}100 \\
106\end{array}$ & $\begin{array}{r}45 \\
100\end{array}$ & $\begin{array}{r}52 \\
100\end{array}$ & $\begin{array}{l}100 \\
200\end{array}$ & $\begin{array}{l}135 \\
100\end{array}$ & \multirow{2}{*}{$\begin{array}{l}50-210 \\
60-136\end{array}$} \\
\hline $\mathrm{Clq}$ & $\left\{\begin{array}{l}\text { After } \\
\text { Before }\end{array}\right.$ & $\begin{array}{r}66 \\
200\end{array}$ & $\begin{array}{l}170 \\
100\end{array}$ & $\begin{array}{r}100 \\
74\end{array}$ & $\begin{array}{l}170 \\
100\end{array}$ & $\begin{array}{l}170 \\
100\end{array}$ & \\
\hline GBG & $\left\{\begin{array}{l}\text { After } \\
\text { Before }\end{array}\right.$ & $\begin{array}{l}100 \\
100\end{array}$ & $\begin{array}{r}74 \\
100\end{array}$ & $\begin{array}{l}100 \\
100\end{array}$ & $\begin{array}{r}74 \\
100\end{array}$ & $\begin{array}{l}100 \\
100\end{array}$ & \multirow{2}{*}{$\begin{array}{l}40-210 \\
40-210\end{array}$} \\
\hline $\begin{array}{l}\text { Proper- } \\
\text { din }\end{array}$ & After & 70 & 100 & $\begin{array}{l}\text { Not } \\
\text { done }\end{array}$ & 60 & 100 & \\
\hline
\end{tabular}

found in three of four patients and they returned to normal with treatment (see fig. 4). In case 2 the $\mathrm{C} 3$ concentrations fell again during relapse and returned to normal after excision of the infected valve. $\mathrm{C} 4$ concentrations were persistently low in case 2 and rose to the lower limit of normal after excision of the infected valve. The other two patients with low C3 concentrations had C4 concentrations of $52 \%$ and $72 \%$, which rose to $100 \%$ after treatment. $\mathrm{Clq}, \mathrm{GBG}$ and properdin concentrations were normal in all patients.

\section{Discussion}

Three features of interest emerged from our studies of these patients: evidence for an immune complex nephritis in three patients with segmental histological changes, our failure to identify the pathogenetic mechanism in the two patients with diffuse proliferative glomerulonephritis, and the severity of renal involvement in four of the five patients.

Evidence suggesting that glomerular disease was the result of circulating antigen-antibody complexes was present in all three patients with focal (segmental) nephritis. The reduction in the concentrations of $\mathrm{C} 3$ and $\mathrm{C} 4$ suggested activation of the classical complement pathway and deposits of immunoglobulin and C3 were found in their glomeruli. These deposits were subendothelial in the patients in cases 1 and 2 (see fig. 5) and mainly mesangial in case 3. Studies of experimental immune complex nephritis (Germuth et al., 1972) have shown that the site of deposition within the glomerulus depends on the size of the immune complexes. It seems that relatively small complexes formed in antigen excess localize in a subepithelial position and are associated with a diffuse proliferation, whereas larger complexes formed in antibody excess deposit on the inside of the glomerular basement membrane or in the mesangium and are accompanied by a focal nephritis. These findings suggest that complexes were formed in antibody excess in cases 1-3. It is interesting that in the preantibiotic era death from renal failure associated with bacterial endocarditis most often occurred in patients in whom blood cultures were repeatedly sterile-the so-called bacteria-free stage. Such patients had a chronic illness sometimes lasting decades associated with massive splenomegaly, lymphadenopathy, and profound anaemia (Libman and Freiberg, 1948). Probably these patients had prolonged circulation of immune complexes formed in antibody excess accounting for the sterile blood cultures and the hyperplastic reticuloendothelial system. In acute endocarditis, however, infected blood cultures, indicating excess antigen, are associated with diffuse proliferative glomerulonephritis (Heptinstall, 1966) and immunofluorescent and ultrastructural studies (Gutman et al., 1972; $\mathrm{Tu}$ et al., 1969) have shown subepithelial deposition of complexes.

Our attempts to show the antigens of the infecting organisms in the glomerular deposits-that is, to provide direct evidence of immune-complex nephritis-were unsuccessful. Other workers, however, have occasionally succeeded in identifying antigens or eluting specific antibody. Coxsackie B4 antigen was shown to be present in the glomeruli of a patient who had viral pancarditis (Burch et al., 1969), and antibody to enterococci was eluted from the kidney of another patient with endocarditis due to this organism (Levy and Hong, 1973). Studies of experimentally induced immune-complex nephritis (Wilson and Dixon, 1971) have shown that antigen becomes obscured to immunofluorescent reagents by further deposition of antibody and complement, particularly in the mesangial deposits formed in antibody excess (Germuth and Rodriguez, 1973). Previous immunofluorescent studies (McIntosh et al., 1971; Berman and Myers, 1972; Gutman et al., 1972) in subacute infective endocarditis have usually shown evidence of immune-complex deposition in both the focal and diffuse forms of glomerulonephritis: Morel-Maroger et al. (1972) found granular deposits of C3 in the biopsies of patients who had no clinical evidence of renal involvement and Gutman et al. (1972) found deposits of IgG and $\mathrm{C} 3$ six months after treatment when the patient was clinically well. These studies suggest that immune complex deposition is the most common cause of both focal and diffuse proliferative glomerulonephritis.

We cannot explain the pathogenesis of diffuse glomerulonephritis in cases 4 and 5 . No evidence of immune-complex deposition was obtained by immunofluorescent or ultrastructural studies. One other patient with subacute infective endocarditis whose biopsy did not contain immunoglobulins or C3 has been reported (Morel-Maroger et al., 1972). This patient had no clinical evidence of renal involvement but a renal biopsy showed focal nephritis. Proliferative nephritis associated with polyarteritis nodosa (Berger et al., 1971; McIntosh et al., 1971) and, more rarely, Goodpasture's syndrome (Berger et al., 1971) have also been described without deposits of immunoglobulin or C3 in the affected glomeruli. The mechanism of glomerular injury in these situations remains to be identified.

Immunological studies of these patients were clinically valuable. Immunofluorescent studies help in differentiating the focal nephritis of subacute infective endocarditis from the histo- 
logically similar appearances seen in polyarteritis nodosa, Goodpasture's syndrome, Henoch-Schönlein syndrome, and idiopathic focal nephritis associated with mesangial $\operatorname{IgA} / \operatorname{IgG}$ deposits (Berger, 1969; Berger et al., 1971). Serial determinations of serum complement were valuable in assessing activity of the immune-complex disease and its response to therapy, and in one of our patients the fall in plasma C3 concentration was helpful in diagnosing relapse.

Even before the advent of antibiotics renal failure in subacute infective endocarditis was unusual (Baehr, 1921). It was, however, a striking feature in this group of patients, four of whom needed peritoneal dialysis. Two of these patients recovered good renal function, one died of cardiac failure shortly after admission, and the fourth patient, with extensive glomerular destruction, had irreversible renal failure. In one of the patients who recovered there was also clinical and histological evidence of acute tubular necrosis but in the remaining patients renal failure was due solely to glomerulonephritis. The striking improvement in renal function after eradication of infection emphasizes the importance of persistence of antigen in the progression of nephritis and the degree of recovery that is possible unless widespread glomerular scarring has already occurred. The importance of early diagnosis and effective treatment is evident.

We should like to thank Professor J. P. Shillingford and Professor J. F. Goodwin for allowing us to study their cases and Miss Jane Fallows and Dr. Gwyn Williams for help with studies of the complement system.

\section{References}

Baehr, G. (1921). Archives of Internal Medicine, 27, 262.

Berger, J. (1969). Transplant Proceedings, 1, 939.

Berger, J., Yaneva, H., and Hinglais, N. (1971). In Advances in Nephrology, ed. J. Hamburger, J. Crosnier and M. H. Maxwell, Chicago, Year Book Medical Publishers.

Berman, L., and Myers, A. M. (1972). South African Medical fournal, 46, 850 .

Burch, G. E., and Colcolough, H. L. (1969). Annals of Internal Medicine, $71,963$.

Evans, D. J., et al., (1973). British Medical fournal, 3, 326

Feltkamp, T. E. W., and Boode, J. H. (1970). Fournal of Clinical Pathology, 23, 629.

Germuth, F. G., Senterfit, L. B., and Dressman, G. R. (1972). Fohns Hopkins Medical fournal, 130, 344.

Germuth, F. G., and Rodriguez, E. (1973). Immunopathology of the Renal Glomerulus, Boston, Little, Brown \& Co.

Gutman, R. A., Striker, G. E., Gilliland, B. C., and Cutler, R. E. (1972). Medicine, 51, 1.

Heptinstall, R. H. (1966). Pathology of the Kidney, p. 330. London, Churchill. Levy, R. L., and Hong, R. (1973). American fournal of Medicine, 54, 645.

Libman, E., and Freiberg, L. K. (1948). Sub-acute Bacterial Endocarditis. 2nd edn., p. 364. New York, Oxford Medical Publications.

McIntosh, R. M., et al., (1971). Quarterly fournal of Medicine, 40, 385.

Macanovic, M., Evans, D. J., and Peters, D. K. (1972). Lancet, 2, 207.

Meyer, K. F., Eddie, B., and Schachter, J. (1969). In Diagnostic Procedures for Viral and Ricketsial Infections, ed. E. H. Lenette and N. J. Schmidt, 4th edn., New York, American Public Health Association Incorporated. Morel-Maroger, L., Sraer, J. D., Herreman, G., and Godeau, P. (1972). Archives of Pathology, 94, 205.

Nairn, R. C. (1969). Fluorescent Protein Tracing, 3rd edn., p. 303. Edinburgh, Livingstone.

Tu, W. H., Shearn, M. A., and Lee, J. C. (1969). Annals of Internal Medi-

Williams, D. G., Charlesworth, J. A., Lachmann, P. J., and Peters, D. K. (1973). Lancet, 1, 447.

Wilson, C. B., and Dixon, F. J. (1971). Fournal of Experimental Medicine, 134, $7 \mathrm{~S}$.

\title{
Response to Propranolol and Diazepam in Somatic and Psychic Anxiety
}

\author{
P. J. TYRER, M. H. LADER
}

British Medical fournal, 1974, 2, 14-16

\section{Summary}

A total of 12 chronically anxious psychiatric outpatients were treated with racemic propranolol (Inderal), diazepam (Valium), and placebo for one week each, using a balanced cross-over experimental design. Six patients had predominantly somatic anxiety, complaining mostly of bodily symptoms, and six had mainly psychic anxiety, complaining primarily of psychological symptoms. Clinical ratings of anxiety were made by patient and psychiatrist after each treatment. Though diazepam was in general more effective than propranolol or placebo in relieving anxiety, propranolol was more effective than placebo in patients with somatic anxiety but not in those with psychic anxiety. We suggest that propranolol should be reserved for patients whose anxiety symptoms are mainly somatic.

Bethlem Royal and Maudsley Hospitals, London S.E.5

P. J. TYRER, M.R.C.P., M.R.C.PSYCH., M.R.C. Clinical Research Fellow and Honorary Senior Registrar (Present address: Department of Psychiatry, South Block, Southampton General Hospital, Southampton)

Institute of Psychiatry, De Crespigny Park, Denmark Hill, London SE5 5AF

M. H. LADER, M.D., M.R.C.PSYCH., Reader in Clinical Psychopharmacology
Introduction

Granville-Grossman and Turner (1966) were the first to suggest that beta-adrenoceptor blockade might be effective in the treatment of pathological anxiety. Some more recent reports suppont this view (Wheatley, 1969; Conway, 1971; Bonn et al., 1972; McMillin, 1973). Nevertheless, neurotic anxiety is not commonly treated with beta-blocking drugs and there are no clear indications for their use. Granville-Grossman and Turner (1966) found that only autonomically mediated symptoms were significantly improved by propranolol; anxiety, tension, and irritability were not. In view of the known peripheral effects of beta-adrenoceptor blockade these findings were not unexpected, but to what extent a reduction in autonomic symptoms creates clinical improvement is debatable (Ramsay et al., 1973). Anxious patients vary greatly in their emphasis on the somatic or the psychological aspeots of their anxiety. We took this into account in planning the present investigation of the effects of propranolol compared with those of diazepam and placebo in anxious patients.

\section{Patients and Methods}

Outpatients attending the Maudsley Hospital with a primary diagnosis of chronic anxiety state (continuous symptoms for at least four months) were considered for the trial. Patients with cardiac disease and asthma were excluded. Out of 15 patients selected one group suffered mainly from somatic anxiety, placing most emphasis on bodily symptoms, and another group 